\title{
INFLUENCE OF DIFFERENT ROOTSTOCKS ON SOME QUALITY PARAMETERS OF GRAFTED MELON SEEDLING
}

\author{
Aynur ÖZBAHÇE ${ }^{*}$, Ceren GÖRGIŞEN² ${ }^{2}$ Rohat GÜLTEKINN ${ }^{3}$, Yakup KÖSKER ${ }^{4}$, Şeyma DEMİRCís, \\ Ali Fuat TARI' ${ }^{6}$ Erdal GÖNÜLAL ${ }^{7}$
}

${ }^{1}$ Doç. Dr., Selcuk University, Cumra Vocational School, Department of Park and Horticulture, Konya; ORCID: 0000-0001-7199-176X ${ }^{2}$ Dr., Soil, Fertilizer and Water Resources Central Research Institute, Ankara; ORCID: 0000-0002-8348-1094

${ }^{3} \mathrm{Dr}$., Soil, Fertilizer and Water Resources Central Research Institute, Ankara; ORCID: 0000-0001-9834-4765

${ }^{4}$ Dr., Soil, Fertilizer and Water Resources Central Research Institute, Ankara; ORCID: 0000-0001-5628-6587

${ }^{5}$ Research Institute for Combating Soil Water Desertification, Konya; ORCID: 0000-0000-0000-0000

${ }^{6}$ Doç. Dr., Harran U. Faculty of Agriculture Dept. of Agricultural Structures and Irrigation, Şanliurfa; ORCID: 0000-0001-9157-1682

${ }^{7}$ Dr., Bahri Dagdas International Agricultural Research Institute, Konya; ORCID: 0000-0002-1621-0892

Geliş Tarihi / Received: 24.02.2021

Kabul Tarihi / Accepted: 15.10.2021

\begin{abstract}
This study was conducted to determine the effects of different rootstocks on some growth characteristics of grafted melon seedlings under greenhouse condition in 2020. In the study, four different rootstocks were used: 1-Ungrafted, 2-Ferro, 3Maximus and TZ148. Edal1 $\mathrm{F}_{1}$ variety (Cucumis melo var. Edal1 $\mathrm{F}_{1}$ ) was used as a scion. The experiment was conducted in a completely randomized block design with three replications. Melon and rootstocks seeds were sown on 28.04.2020 and rootstock seeds on 03.05.2020, respectively. Grafting was done on 15.05.2020 and was performed through the splice grafting method. Some growth characteristics studied on melon seedlings were fresh-dry seedling weights (FSW-DSW), stem diameter-height (SD-SH), leaf number-length (LN-LL), fresh-dry root weights (FRW-DRW), root height (RH) and chlorophyll content (CC-SPAD) and some macro-micro nutrient contents. According to the results of statistical analyses, positive differences were found in the grafted seedlings compared to non-grafted seedlings at these parameters $(p<0.01)$. In many of the seedling quality values, Ferro and Maximus hybrids stood out temper to others. Also, in the experiment, correlations between FSW and SD, RH, SPAD and total N content were found significant.
\end{abstract}

Keywords: Melon, grafting, rootstock, seedling quality, SPAD

\section{AŞILI KAVUN FIDELERININ BAZI KALITE PARAMETRELERİ ÜZERİNE FARKLI ANAÇLARIN ETKİSI}

\section{ÖZ}

Bu çalışma, 2020 yılında sera koşullarında aşılı kavun fidelerinin bazı büyüme özelliklerine farklı anaçların etkilerini belirlemek amacıyla yapılmıştır. Denemede 1-Aşılanmamış, 2-Ferro, 3-Maximus ve TZ148 olmak üzere dört farklı anaç kullanılmıştır. Kalem olarak Edalı $\mathrm{F}_{1}$ çeşidi (Cucumis melo var. Edalı $\mathrm{F}_{1}$ ) seçilmiştir. Deneme tesadüf bloklar halinde üç tekerrürlü olarak kurulmuştur. Kavun tohumları 28.04.2020, anaç tohumları ise 03.05.2020 tarihlerinde ekilmiştir. 15.05.2020 tarihinde aşılama yapılmıştır. Aşılama kotiledon birleştirme yöntemi ile yapılmıştır. Kavun fidelerinde incelenen bazı parametreler; büyüme özellikleri, taze-kuru fide ağırlıkları (FSW-DSW), gövde çapı-yüksekliği (SD-SH), yaprak sayısı ve uzunluğu (LN-LL), taze-kuru kök ağırlıkları (FRW-DRW), kök yüksekliği (RH) ve klorofil içeriği (CCSPAD) ve bazı makro-mikro besin içerikleridir. İstatistiksel olarak bu parametrelerde aşılı fidelerde aşılanmamışlara göre pozitif farklar bulunmuştur $(\mathrm{p}<0.01)$. Fide kalite değerlerinin çoğunda, Ferro ve Maximus anaçları diğerlerine göre daha öne çıkmıştır. Ayrıca denemede FSW ile SD, RH, SPAD ve toplam N içeriği arasındaki korelasyonlar arasındaki farklar da önemli bulunmuştur.

Anahtar Kelimeler: Kavun, aşılama, anaç, fide kalitesi, SPAD

\section{INTRODUCTION}

The use of grafted watermelon (Citrullus lanatus) became a standard production practice in Japan in the 1930s. This was used to manage a soil-borne disease (Verticillium, Fusarium and Meloidogyne spp.). Thereafter, grafting was soon applied to melons
(Cucumis melo). The use of grafted plants in production has been increased with the ban of the broad-spectrum soil fumigant methyl bromide $[8,17$, 27, 20].

Today, in some regions of Asia and Europe, commercial use of grafted watermelon plants is composed of up to $95 \%$ of total watermelon 
production [17]. Other than disease management, also, grafted plants are used to manage salinity in soil and irrigation water. To manage soil-borne diseases in grafted watermelon and melon plants are primarily by providing a more vigorous, disease-resistant root system [10]. Grafting has become widespread; not only to control to biotic stress such as soil-borne pathogens but also to provide tolerance to abiotic stress such as drought, cold, salinity stress and heavy metal toxicity $[22,11]$.

There are a limited number of studies on grafted vegetable production. However, recently, investigations to grafting by researchers and commercial firms have increased with the banning of methyl bromide. Suitable rootstocks should be identified and characterized by the effective utilization of grafting. Vegetables of Cucurbitaceae family are grown in all regions of Turkey and there is great genetic diversity [28, 30]. Antalya Province, where a significant amount of protected vegetable cultivation occurs is especially located in the grafted seedling industry in Turkey [29].

In Turkey, the production of grafted commercial seedlings first began in tomatoes in 1998 [26]. Studies have shown that the strong root system of the rootstock is more effective in the intake of water and plant nutrients in grafted plants than in unvaccinated plants. As a result, it has been determined that the growth performance of the rootstocks has a positive effect on the product increase and disease control. On the other hand, as a result of poor compatibility between rootstock and scion, it causes negative effects such as product loss, deterioration of fruit quality and death of plants [15].

Techniques commonly used in grafted watermelon and melons are three: one cotyledon splice, hole insertion and tongue-approach $[8,12,33]$; however, in commercial production, the one cotyledon and hole insertion grafts are most commonly used today $[8,14]$. The use of high-quality seedlings is a necessity for successful crop establishment and grafted vegetable seedling used is rapidly expanding in both field and greenhouse cultivation.

A study showed that the number of leaves, stem length and fresh weight of melon plants increased using 22 different Cucurbita spp. rootstocks. It was demonstrated that rootstocks affect the number of nodes and lateral branches and that the vigour of grafted watermelon plants was improved when grafted onto a gourd rootstock. It showed that grafting did not affect length [9].

Grafts were used to enhance nutrient uptake [18]. Ruiz and Romero [23], studied $\mathrm{N}$ metabolism in grafted melon plants, observed that the use of certain rootstocks in squash enhanced $\mathrm{NO}_{3}{ }^{-}$reduction and $\mathrm{N}$ use, defined as an increase in the content of organic $\mathrm{N}$ in leaf tissue. However, the response of grafted melon to $\mathrm{N}$ was investigated at one level of nitrate in the nutrient solution, whereas information was lacking concerning the influence of different levels of nitrate on grafted melon crop performance.

Colla et al. [6], conducted to improve nitrogen efficiency in melon by grafting. The results indicated that the total leaf area, SPAD index and shoot $\mathrm{N}$ uptake increased linear and quadratic in response to an increase of the $\mathrm{N}$ concentration in the nutrient solution.

Guan and Zhao [13], used grafting for controlling certain soil-borne diseases and abiotic stress tolerance in muskmelon (Cucumis melo) production. The experiment was conducted under greenhouse conditions. Four grafting methods (hole insertion, one-cotyledon, non-cotyledon and tongue approach) were examined for their impacts on plant growth and root characteristics. As a result, grafted plants with root excision started to show active and rapid root regeneration at 8 days after grafting (DAG) and reached a similar root length and surface area as the root-intact plants at 16 DAG.

In grafting studies, there are fewer studies in melons than watermelons in Turkey. Thus, more experiments on potential melon the rootstocks and characteristics of candidates in germplasm will be of great value. The purpose of the experiment was to determine the effects of different rootstocks on some growth characteristics of grafted melon seedling under greenhouse condition in 2020.

\section{MATERIALS AND METHODS}

\section{Material}

In the experiment, three rootstocks and one melon cultivar were used. The rootstocks were Ferro, Maximus and TZ148. The scion was Edal1 $F_{1}$ (Cucumis melo var. Edal1 $\mathrm{F}_{1}$ ). All the rootstocks are Cucurbita maxima $\times$ Cucurbita moschata hybrids.

Features of used rootstocks and scion (melon variety) in the experiment

The characteristics of the rootstocks used in the study are determined as follows.

-Ferro (C. maxima $\times$ C. moschata): It is resistant to Fusarium oxysporum. It does not cause fibrillation in the fruit flesh. It provides a stronger development.

-Maximus (C. maxima $\times$ C. moschata): Especially in watermelons, "Maximus" rootstock, which is known to be resistant to wilting (Fusarium 
oxysporum f.sp. niveum), was used. Rootstock is a medium strong rootstock, it provides a high yield in the variety it is grafted to and it has no negative effect on the taste, shape and other quality elements of the fruit.

-TZ 148 (C. maxima $\times$ C. moschata): This rootstock is resistant to Fusarium spp., Verticillium spp., Phompsis spp. and Melodoigyne spp.

-Scion-Variety (Edal1 $F_{1}$ ): Edal1 $F_{1}$ (Cucumis melo var. Edal1 $\left.F_{1}\right)$, a registered melon variety widely used in cultivation in the region, was used as the scion. The variety is susceptible to soil-borne pathogens. Its plant is big and strong. Its fruit is 'hıdır'* type, oval and green freckled on a yellow background. The flesh is thick and firm. The ripening period is medium late. Fruit weight is $2-2.5 \mathrm{~kg}$.

\section{Cultural conditions}

The scion variety and rootstocks seeds were sown on 28.04.2020, 03.05.2020 and early spring, respectively. The study was conducted under controlled greenhouse conditions, in Antalya, Turkey. The seeds were sown into 120-cell in black polyethylene pots filled with a potting mix containing (turba, perlite and pumice). Grafting was done on 15.05.2020. Seedlings were grown in the greenhouse until they became both rootstock and scion. The growth periods of scion and grafted seedlings were 32-27 days, respectively. Also, 15 days had passed after grafting. The seedling measurement was made on 31.05.2020. Plants were grown under controlled conditions, with a relative humidity of $60-80 \%$, a temperature of $18-25^{\circ} \mathrm{C}$, a photoperiod of $15 \mathrm{~h}$ and an irradiance of $245 \mu \mathrm{mol} \mathrm{rn}^{-2} \mathrm{~s}^{-1}$. Plants were fertilized with macro and microelements with fertigation as follows:

\section{Fertilization}

$\mathrm{N}\left(\mathrm{NH}_{4} \mathrm{NO}_{3}-0.25 \mathrm{~mol} \mathrm{l}^{-1}\right), \mathrm{K}\left(\mathrm{KNO}-0.20 \mathrm{~mol} \mathrm{l}^{-1}\right)$ and $\mathrm{P}\left(\mathrm{H}_{3} \mathrm{PO}_{4}-0.14 \mathrm{~mol} \mathrm{l}^{-1}\right), \mathrm{Ca}\left(\mathrm{CaCO}_{3}-0.08 \mathrm{~mol} \mathrm{l}^{-1}\right)$, $\mathrm{Mg}\left(\mathrm{MgSO}_{4}-0.04 \mathrm{~mol} \mathrm{l}^{-1}\right)$ and $10 \mu \mathrm{MFe}$ (FeEDDHA) were supplied as sulphates. The other micronutrients $(\mu \mathrm{M})$ were applied as sulphates: $3 \mathrm{Mn}, 2 \mathrm{Zn}, 0.4 \mathrm{Cu}$ and $0.7 \mathrm{Mo}$. The $\mathrm{pH}$ value of the solution was regulated between 6 and 7. The fertilizer applications to plants were fertigated with a drip irrigation system.

\section{Plant grafting}

One cotyledon splice method was used as a grafting technique as follows. The "one cotyledon graft" is also known as "splice", "slant" or "tube" graft [14]. The one cotyledon grafting method applied for watermelon and melons is the most popular method used [20]. Plants are ready for grafting when the first true leaf is present on the rootstock or as young as the scion cotyledon stage [7].

One cotyledon grafting technique

Grafting was done when rootstocks seedlings had one true leaf and scion seedlings had two true leaves. The rootstock was cut at an approximately $60^{\circ}$ angle [21] and one cotyledon remained and one was removed. The remaining cotyledon was meticulous cut to keep hardly connected to the rootstock stem. So, the angled cut was also removed from the apical meristem in the remaining cotyledon. All the apical meristem was removed to prevent future shoot growth of the rootstock. After, the scion was cut at an approximately $60^{\circ}$ angle from below the cotyledons. The diameter of the cutting scion was made to suit the diameter of cutting the rootstock (Figure 1).

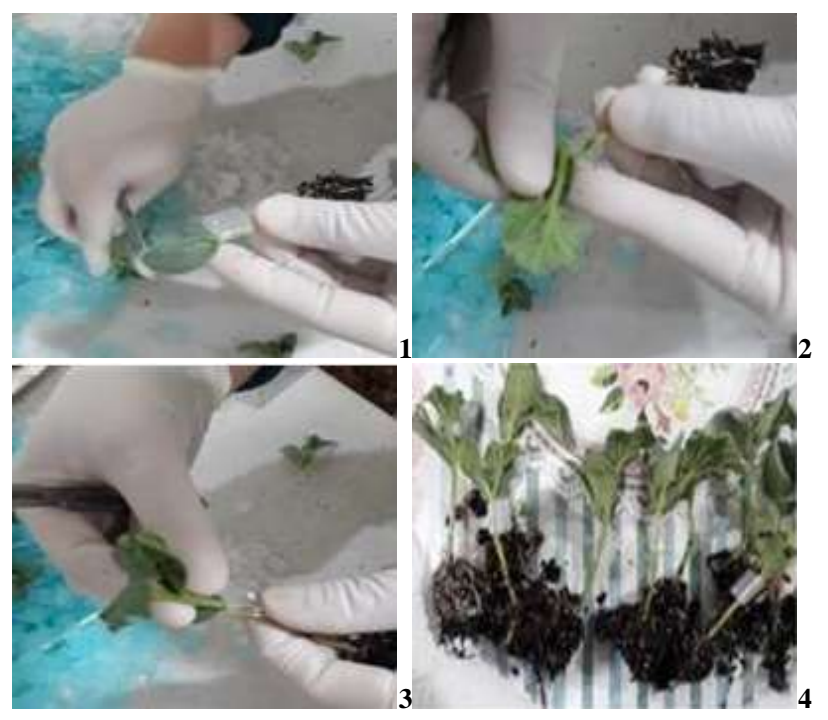

Figure 1. One cotyledon grafting: (1) cut the rootstock at a $60^{\circ}$ angle with one cotyledon remaining on the plant; (2) cut the scion at a $60^{\circ}$ angle from below the cotyledons (its diameter matches that of the rootstock) (3) attach cut scion and rootstock stems together; and (4) secure the graft with a grafting clip

Afterward, a special environmental condition, which was high levels of dark, humidity and approximately $23^{\circ} \mathrm{C}$ in the environment were quickly provided for grafted seedlings require. This condition provided minimizes environmental stresses and photosynthetic activity until healing was complete. Grafted seedlings were kept under the conditions for approximately eight days. Four days into graft healing, light intensity was increased and humidity was gradually decreased in the stage to prepare the seedlings for environmental conditions outside the special conditions. 


\section{Methods}

The treatments were arranged in a randomized complete design with three replications. In the study, fresh-dry seedling weights, stem diameter-length, leaf number-length, fresh-dry root weights, root length, seedling length and chlorophyll content (SPAD) and some macro-micro nutrient contents were examined.

There were 40 seedlings in each treatment. 21 seedlings from each plot were chosen to determine observation and measurements. In the experiment, the measurement parameters were fresh-dry seedling weights (FSW-DSW, g), stem diameter-length (SD$\mathrm{SL}, \mathrm{mm}$ ), leaf number (LN, number)-length (LL, cm), root fresh-dry weights (RFW-RDW, g), root length (RL, cm), seedling length (SL, cm) and chlorophyll content (SPAD) and some macro (\%)-micro nutrient (ppm) contents. The chlorophyll content was measured by a chlorophyll meter (SPAD). The nutrient content was determined by the diethylene triamine penta acetic acid (DTPA) extraction method by ICP [19]. The seedlings (stem, leaf except for the root) samples were dried at $68^{\circ} \mathrm{C}$ for $48 \mathrm{~h}$ until it reaches constant weight. To determine total $\mathrm{N}$ content was used by The Kjeldahl method [4]. Statistical analyzes were made according to Duncan test by Yurtsever [32].

\section{RESULTS AND DISCUSSION}

The effect of grafting on some seedling quality traits in melon is shown in Table 1.

According to statistical analysis, there was a significant at $99 \%$ reliable level of differences between rootstocks and scion (FWS, DSW SD, SH, LN, LL, RWW, RDW, RH and CC parameters) $(\mathrm{p}<0.01)$. The highest FSW $(9.00 \mathrm{~g})$, DSW $(0.67 \mathrm{~g})$, SD (5.71 mm), RFW (1.10 g) and CC (44.97) were determined at Maximus rootstock. At FSW (8.93 g), CC (42.52), Ferro rootstock followed Maximus. SH $(10.08 \mathrm{~cm}), \mathrm{LN}(5.52$ number) and RDW (0.09 g) were higher at Ferro rootstock. Maximus (SH-9.97 $\mathrm{cm}, \mathrm{RDW}-0.08 \mathrm{~g}$ ) followed the rootstock. Also, TZ 148 (LN-4.86 number) followed Ferro. The high RH $(13.59 \mathrm{~cm})$ was established at TZ 148. Maximus (RH$12.62 \mathrm{~cm})$ and Ferro (RH-12.60 cm) followed TZ 148. LL $(6.10 \mathrm{~cm})$ was high at Edal1 $F_{1}$ scion. There were no significant between scion (ungrafted seedlings), TZ 148 (LL-6.08 cm) and Maximus (LL$6.02 \mathrm{~cm}$ ) hybrids.

Macro and micro nutrient contents of grafted and non-grafted seedlings were presented in Table 2. It was significant at $99 \%$ reliable level of differences between rootstocks and scion $(\mathrm{p}<0.01)($ Table 2$)$.

Table 1. Effect of grafting on some seedlings quality parameters in melon

\begin{tabular}{|c|c|c|c|c|c|c|c|c|c|c|}
\hline Grafting* & FSW $(\mathrm{g})$ & DSW $(\mathrm{g})$ & SD $(\mathrm{mm})$ & SH $(\mathrm{cm})$ & LN $($ number) & LL $(\mathrm{cm})$ & RFW $(\mathrm{g})$ & RDW $(\mathrm{g})$ & RH $(\mathrm{cm})$ & CC $(\mathrm{SPAD})$ \\
\hline Scion (Ungrafted-Edal1 $\left.\mathrm{F}_{1}\right)$ & $6.78 \mathrm{~d}$ & $0.46 \mathrm{~b}$ & $5.15 \mathrm{~b}$ & $5.86 \mathrm{c}$ & $4.05 \mathrm{c}$ & $6.10 \mathrm{a}$ & $0.53 \mathrm{c}$ & $0.06 \mathrm{~b}$ & $11.50 \mathrm{c}$ & $38.64 \mathrm{c}$ \\
\hline Ferro & $7.46 \mathrm{c}$ & $0.63 \mathrm{a}$ & $5.44 \mathrm{ab}$ & $10.08 \mathrm{a}$ & $5.52 \mathrm{a}$ & $5.94 \mathrm{~b}$ & $0.94 \mathrm{ab}$ & $0.09 \mathrm{a}$ & $12.60 \mathrm{~b}$ & $42.52 \mathrm{~b}$ \\
\hline Maximus & $9.00 \mathrm{a}$ & $0.67 \mathrm{a}$ & $5.71 \mathrm{a}$ & $9.97 \mathrm{a}$ & $4.76 \mathrm{bc}$ & $6.02 \mathrm{a}$ & $1.10 \mathrm{a}$ & $0.08 \mathrm{a}$ & $12.62 \mathrm{~b}$ & $44.97 \mathrm{a}$ \\
\hline TZ-148 & $8.93 \mathrm{~b}$ & $0.63 \mathrm{a}$ & $5.42 \mathrm{ab}$ & $9.29 \mathrm{~b}$ & $4.86 \mathrm{~b}$ & $6.08 \mathrm{a}$ & $0.77 \mathrm{~b}$ & $0.07 \mathrm{~b}$ & $13.59 \mathrm{a}$ & $44.30 \mathrm{~b}$ \\
\hline
\end{tabular}

*p<0.01 Mean values followed by different letters within a column are significantly different $(\mathrm{p}<0.01)$

FSW-fresh seedling weight DSW-dry seedling weight SD-stem diameter LN-leaf number LL-leaf length

RFW-root fresh weight RDW-root dry weight RH-root height CC-chlorophyll content

Table 2. Effect of grafting on some total macro and micro nutrient contents of grafted seedling

\begin{tabular}{|c|c|c|c|c|c|c|c|c|c|}
\hline \multirow{2}{*}{ Grafting* } & $\mathrm{N}(\%)^{*}$ & $\mathrm{P}(\%) \mathrm{ns}$ & $\mathrm{K}(\%)^{*}$ & $\mathrm{Ca}(\%) \mathrm{ns}$ & $\mathrm{Mg}(\%)^{*}$ & $\mathrm{Fe}(\mathrm{ppm}) *$ & $\mathrm{Zn}(\mathrm{ppm})^{*}$ & $\mathrm{Cu}(\mathrm{ppm})^{*}$ & $\mathrm{Mn}(\mathrm{ppm}) *$ \\
\cline { 2 - 9 } & \multicolumn{7}{|c|}{ Macro Nutrients } & \multicolumn{4}{|c|}{ Micro Nutrients } \\
\hline Scion (Edalı $\left.\mathrm{F}_{1}\right)$ & $6.3 \mathrm{ab}$ & 1.0 & $5.1 \mathrm{ab}$ & 4.1 & $1.5 \mathrm{~b}$ & $109.9 \mathrm{~d}$ & $49.8 \mathrm{c}$ & $93.7 \mathrm{~d}$ & $92.5 \mathrm{~b}$ \\
\hline Ferro & $7.2 \mathrm{a}$ & 1.1 & $5.9 \mathrm{a}$ & 4.0 & $1.5 \mathrm{~b}$ & $149.6 \mathrm{a}$ & $63.6 \mathrm{a}$ & $285.8 \mathrm{~b}$ & $105.6 \mathrm{a}$ \\
\hline Maximus & $4.2 \mathrm{c}$ & 0.9 & $4.8 \mathrm{~b}$ & 4.4 & $1.3 \mathrm{~b}$ & $126.8 \mathrm{~b}$ & $44.1 \mathrm{c}$ & $323.7 \mathrm{a}$ & $107.9 \mathrm{a}$ \\
\hline TZ148 & $5.9 \mathrm{~b}$ & 1.1 & $5.3 \mathrm{a}$ & 4.0 & $2.3 \mathrm{a}$ & $120.8 \mathrm{c}$ & $53.3 \mathrm{~b}$ & $161.3 \mathrm{c}$ & $94.5 \mathrm{~b}$ \\
\hline
\end{tabular}

${ }^{*} \mathrm{p}<0.01$ NS: Non Significant; Mean values followed by different letters within a column are significantly different $(\mathrm{p}<0.01)$

The highest N (7.2\%), K (5.9\%), Fe (149.6 ppm), $\mathrm{Zn}(63.6 \mathrm{ppm})$ content were occurred at seedling grafted with Ferro rootstock. The highest total $\mathrm{Mg}$ $(2.3 \%)$ was at TZ 148 treatments. Maximus rootstock was distinguished in total $\mathrm{Cu}(323.7 \mathrm{ppm})$ and $\mathrm{Mn}$ (107.9 ppm) contents. Total $\mathrm{P}$ and $\mathrm{Ca}$ had no significant differences among grafted seedlings $(\mathrm{p}<0.01-0.05)$. The results of the experiment have shown that grafting significantly increases both nutrient elements, except the $\mathrm{P}$ and $\mathrm{Ca}$ in the seedlings.

There was a difference between the rootstocks. The N, K, Fe and $\mathrm{Zn}$ content in the seedling was altered by Ferro rootstocks used. The copper and Mn content were found to be higher in the Maximus rootstock than in the others. The $\mathrm{Mg}$ content was determined by the TZ 148 hybrid.

Also, there were significant correlations between FSW and SD, RH, SPAD and total N content in the 
experiment. In the grafted seedlings, these parameters had significant positive correlations. Regression coefficients were $0.64,0.65,0.88$ and 0.50 , respectively, (Figure 2). The correlations were not found among other parameters.
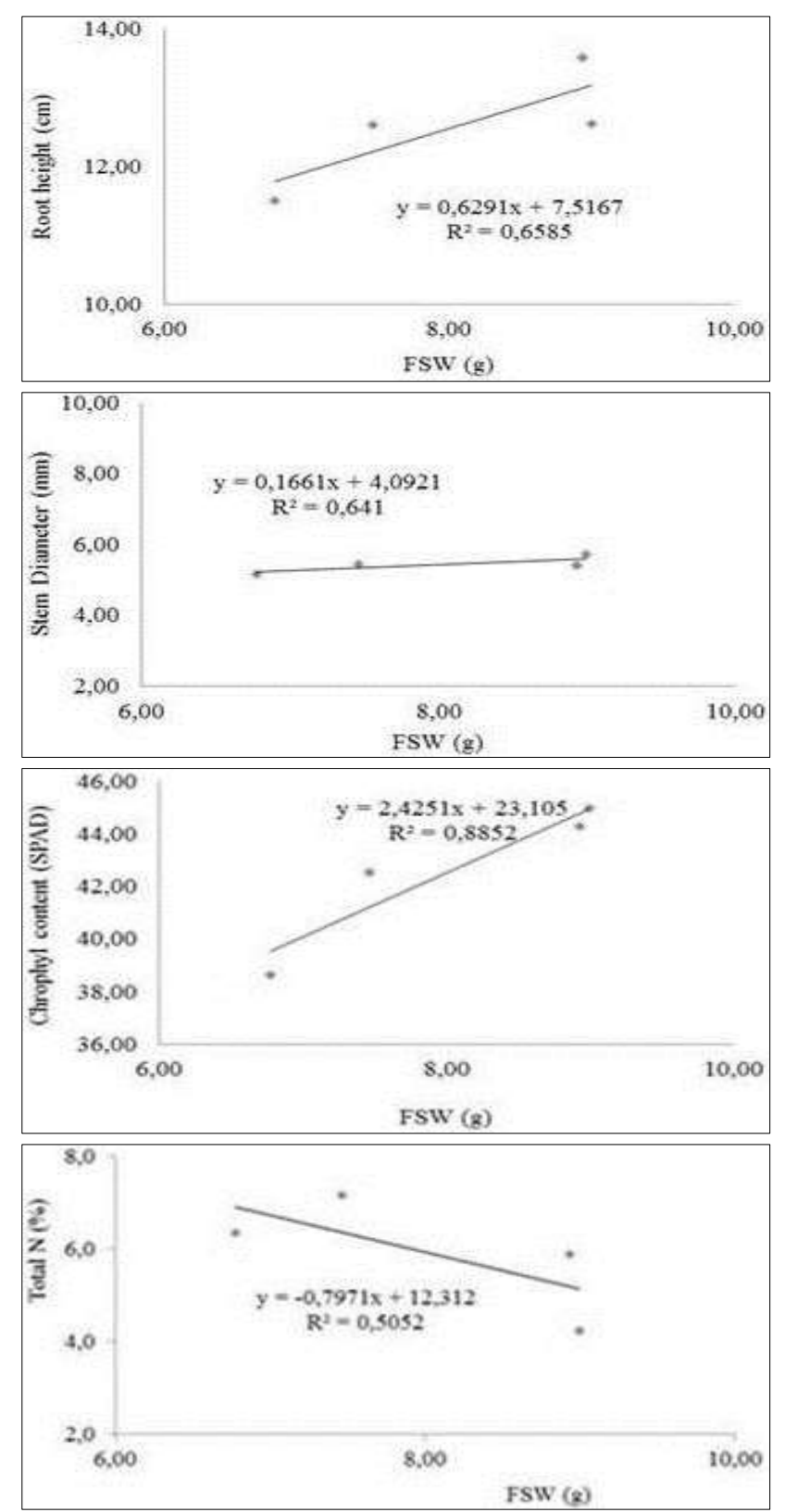

Figure 2. Regression equation between FSW (fresh seedling weight) and Stem diameter, foot height, SPAD and total $\mathrm{N}$ content in leaf

A study was conducted to determine the impact of scion and rootstock seedling quality selection on the vigour of watermelon-inter-specific squash grafted seedlings. The grafted seedlings demonstrated high values in seedling quality traits, such as stem diameter, leaf area and shoot and root dry weight, as well as shoot dry weight-length. It determined objective criteria for the determination of watermelon and inter-specific squash quality to enhance grafted seedling production [2]. Moreover, several research groups $[16,13,1]$ established the importance of scion-rootstock hybrid interactions for the quality of watermelon and muskmelon.

Another experiment was carried out to improve nitrogen efficiency in watermelon and melon by grafting by Bulgar et al. [3] and Colla et al. [6]. The results indicated that the total leaf area, SPAD index and shoot $\mathrm{N}$ uptake increased linearly and quadratic in response to an increase of the $\mathrm{N}$ concentration in the nutrient solution. A study was conducted on some physical and chemical parameters of the grafted seedling. As the result, it was provided advantages for these mineral matters such as $\mathrm{P}, \mathrm{K}, \mathrm{Ca}, \mathrm{Mg}, \mathrm{Fe}, \mathrm{Zn}$ and $\mathrm{Mn}$ in grafted watermelon plants compared to non-grafted [25, 31]. However, the literature lacks information about proper scion-rootstock seedling quality combinations for increasing the quality of grafted melon seedlings.

Ceylan et al. [5], conducted to determine the effects of grafting and rootstock and scion combinations on the yield and nutrient content for both the leaves and fruit of watermelons. As a result, the more $\mathrm{Fe}, \mathrm{Cu}$ and $\mathrm{Zn}$ content in the leaves was observed in the rootstocks. The $\mathrm{K}$ and Fe contents in the leaf were also found to be significant between the varieties. In agreement with some studies; SDW (shoot dry weight) with grafting increased with increasing nitrate availability [24].

\section{CONCLUSION}

According to the results, an increase in many quality parameters of grafted seedlings was observed. FSW, DSW, SD, RFW and SPAD were higher at Maximus rootstock than other rootstocks and scion. Ferro rootstock followed Maximus in these parameters. SH, LN and RDW values were high at Ferro rootstock. At these values ( $\mathrm{SH}$ and $\mathrm{RDW}$ ), Maximus followed the rootstock. Also, TZ 148 followed Ferro. The high RH was determined at TZ 148 hybrid. Maximus and Ferro followed TZ 148. LL level was high at Edalı $F_{1}$ scion. But, at the LL value, there were no significant between scion, TZ 148 and Maximus.

Also, in total N, K, Fe, Zn contents, Ferro hybrid were higher than other rootstocks. The high total $\mathrm{Mg}$ was at TZ 148. Maximus rootstock is distinguished in total $\mathrm{Cu}$ and $\mathrm{Mn}$ contents. In total $\mathrm{P}$ and $\mathrm{Ca}$ values had no significant differences among grafted seedlings. The results of the experiment have shown that grafting significantly increases both nutrient elements, except the $\mathrm{P}$ and $\mathrm{Ca}$ in the seedlings. 
Both seedling quality parameters and macromicro nutrient contents of grafted seedling were increased compared to the scion. On the other hand, in these parameters, Ferro and Maximus rootstocks were higher than TZ 148 and scion.

Also, positive correlations were significantly found between FSW and SD, RH, SPAD and total N content in the experiment.

So, rootstock and scion combinations should be carefully selected according to variety, specific soil, climatic and regional conditions. The relationship between the rootstock-scion may help in the determination of the tolerance of the root system. As it is known, healthy seedlings are the guarantee of abundant and quality products. Also, an appropriate rootstocks selection can increase the yield in commercial melon cultivation. The increase in the examined parameters may have resulted from an increase in water and nutrient uptake due to the strong root system of the rootstock.

\section{ACKNOWLEDGEMENTS}

The study was supported by the General Directorate of Agricultural Research and Policies (TAGEM), Turkey (Project No: TAGEM/TSKAD/B/ 19/A9/P3/888). The authors are thankful to TAGEM for providing funding support.

\section{REFERENCES}

1. Alan, O., F. Sen and E. Duzyaman, 2018. The effectiveness of growth cycles on improving fruit quality for grafted watermelon combinations. Food Sci. Technol. 38:270-277.

2. Bantis, F., A. Koukounaras, A.S. Siomos and C. Dangitsis, 2020. Impact of scion and root stock seedling quality selection on the vigor of watermelon-interspecific squash grafted seedlings. Agriculture 10, 326; 2-10.

3. Bulgar, G., G. Villora, D.A. Moreno and L. Romeo, 2000. Improving the mineral nutrition in grafted watermelon plants: nitrogen metabolism. Biologia Plantarum 43(4):607-609.

4. Bremner, J.M., 1996. Nitrogen-total, methods of soil analysis: part III. In: Sparks D.L., Page A.L., Helmke P.A., Loeppert R.H., Soltanpour P.N., Tabatabai M.A., Johnson C.T., Sumner M.E., editors.

5. Ceylan, S., O. Alan and O.L. Elmac1, 2018. Effects of grafting on nutrient element content and yield in watermelon. Ege University Agriculture Faculty Journal, 55(1):67-74.
6. Colla, G., C.M.C. Suãrez, M. Cardarelli and Y. Rouphael, 2010. Improving nitrogen use efficiency in melon by grafting. HortScience 45(4):559-565.

7. Cushman, K., 2006. Grafting techniques for watermelon. Univ. Fla. Inst. Food Agr. Sci. HS1075:1-5.

8. Davis, A.R., P. Perkins-Veazie, Y. Sakata, S. López-Galarza, J.V. Maroto, S.G. Lee, Y.C. Huh, A. Miguel, S.R. King, R. Cohen and Y.M. Lee, 2008. Cucurbit grafting. Critical Rev. Plant Sci. 27:50-74.

9. Edelstein, M., Y. Burger, C. Horev, A. Pora, A. Meir and R. Cohen, 2004. Assessing the effect of genetic and anatomic variation of cucurbita rootstocks on vigour, survival and yield of grafted melon. J. Hortic. Sci. Biotechnol. 79(3):370-374.

10.Fallik, E., S. Alkalai-Tuvi, D. Chalupowicz, S. Popovsky-Sarid and M. Zaaroor-Presman, 2019. Relationships between rootstock-scion combinations and growing regions on watermelon fruit quality. Agronomy 2019, 9, 536, 2-9.

11.Gaion, L.A., L.T. Braz and R.F. Carvalho, 2017. Grafting in vegetable crops: a great technique for agriculture. International Journal of Vegetable Science 24(1):85-102.

12.Guan, W. and X. Zhao, 2014. Techniques for melon grafting. University of Florida/Institute of Food and Agricultural Sciences Extension EDIS publication HS1257. (http://edis.ifas.ufl.edu/pdf files/HS/HS125700.pdf).

13.Guan, W. and X. Zhao, 2015. Effects of grafting methods and root excision on growth characteristics of grafted muskmelon plants. American Society for Horticultural Science 25(6):706-713.

14.Hassell, R.L. and F. Memmott, 2008. Grafting methods for cucurbit production. HortScience 43:1677-1679.

15.Lee, J.M., 1994. Cultivation of grafted vegetables I. Current status grafting methods and benefits. HortScience 29(4):235-239.

16.Lee, J.M. and M. Oda, 2003. Grafting of herbaceous vegetable and ornamental crops. Hortic. Rev. 28:61-124.

17.Lee, J.M., C. Kubota, S.J. Tsao, Z. Bie, P. Hoyos Echevarria, L. Morra and M. Oda, 2010. Current status of vegetable grafting: Diffusion, grafting techniques, automation. Sci. Hort. 127:93-105.

18.Leonardi, C. and F. Giuffrida, 2006. Variation of plant growth and macronutrient uptake in grafted tomatoes and eggplants on three different rootstocks. Eur. J. Hort. Sci. 71:97-101.

19.Lindsay, W.L. and W.A. Norvell, 1978. Development of a DTPA soil test for zinc, iron, 
manganese and copper. Soil Sci. Soc. Am. J. 42:421-428.

20.Miles, C., P. Devi, X. Zhao and W. Guan, 2017. Grafting manual: how to produce grafted vegetables plants. United States Department of Agriculture, National Institute Food and Agriculture (http://www.vegetablesgrafting.org).

21.Miles, C., L. Hesnault, S. Johnson, P. Kreider and S. Dabirian, 2016. Vegetable grafting: watermelon. Washington State University Extension Publication FS100E, $7 p$.

22.Rivero, R.M., J.M. Ruiz and L. Romero, 2003. Role of grafting in horticultural plants under stress conditions. Food Agric. 1(1):70-74.

23.Ruiz, J.M. and L. Romero, 1999. Nitrogen efficiency and metabolism in grafted melon plants. Sci. Hort. 81:113-123.

24.Sorgonà, A., M.R. Abenavoli, P.G. Gringeri and G. Cacco, 2006. A comparison of nitrogen use efficiency definitions in citrus rootstocks. Sci. Hort. 109, 389-393.

25.Tokgoz, H., M. Goluku, R. Toker and D.Y. Turgut, 2015. Effects of grafting and harvesting time on some physical and chemical parameters of watermelon (Citrullus lanatus). Food (2015) 40(5):263-270 (in Turkish).

26.Tuzel, Y. and A. Ozcelik, 2004. Recent trends and developments in protected cultivation of Turkey. International Workshop on "La Produzione in Serra dopo I'era del bromuro dimetile" 1-3 Nisan Catania/Italy, 189-198.

27.Ulas, F. and H. Yetisir, 2016. Vaccination vegetables: history, use and development of the world in Turkey. Nevşehir Science and
Technology Journal (TARGID) Special Number, pp:345-354.

28. Yetisir, H., 2001. Effect of grafted seedling on plant growth, fruit yield and quality in watermelon and investigation of grafting point histologically (Ph.D. Thesis). Cukurova University Department of Horticulture, Adana-Turkey, 178.

29. Yetisir, H., 2018. History and current status of grafted vegetables in Turkey. 30. International Horticultural Congress, 12-16 August 2018 Istanbul-Turkey, pp:13-18.

30. Yetisir, H. and N. Sar1, 2004. Effect of hypocotyl morphology on survival rate and growth of watermelon seedlings grafted on rootstocks with different emergence performance at various temperatures. Turk J. Agric. (TUBITAK) For 28(2004):231-237.

31. Yuan, H.Y., L. Zhao, Q. Kong, F. Cheng, M. Niu, J. Xi and A.N. Muhammad, 2016. Comprehensive mineral nutrition analysis of watermelon grafted on to two different rootstocks. Horticultural Plant Journal 2(2): 105-113.

32. Yurtsever, N., 1984. Experimental statistics methods. Republic of Turkey, Ministry of Agriculture the former general directorate of rural service, soil-fertilizer research institute. Publication No:121, Techniques Publication No:56, Ankara, Turkey (in Turkish).

33.Zhao, X., W. Guan and D.J. Huber, 2016. Melon grafting in handbook of cucurbits: growth, cultural practices and physiology. M. Pessarakli ed. CRC Press Taylor \& Francis Group, Boca Raton, FL. 